TRAMES, 2016, 20(70/65), 1, 59-73

\title{
SERBIA AND RUSSIA ON THE DEMOGRAPHIC MAP OF EUROPE TWO DECADES AFTER THE FALL OF COMMUNISM
}

\author{
Suzana Lović Obradović ${ }^{1}$, Stefana Babović ${ }^{1}$, Natalia Shpak ${ }^{2}$

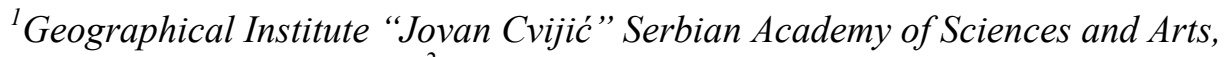 \\ ${ }^{2}$ Ural Federal University
}

\begin{abstract}
The study provides a comprehensive data analysis on total fertility rates, birth rates, life expectancy, percentage share of over 65 year olds, infant mortality rates and adolescent-specific fertility rates, in Russia and Serbia, two decades after the fall of communism and compares it with general values in Europe. The main problems in the demography of Russia and Serbia are connected with economic process, caused by economy transition, from planned economy to the free market, as one of the consequences of the fall. Finally, the authors concluded that the Russian demographic situation is characterized by depopulation processes just like in Serbia.
\end{abstract}

Keywords: fertility rates, birth rates, life expectancy, aging, Serbia, Russia

DOI: $10.3176 /$ tr.2016.1.04

\section{Introduction}

The analysed and presented cartographic data on total fertility rates, birth rates, life expectancy, the percentage share of over 65 year olds, the infant mortality rates and adolescent-specific fertility rates from 2011 are the image of an aging European population with higher values of life expectancy, the number of which decreases, based on the natural movement. The epithet Old Continent can now rightfully refer to Europe even from the standpoint of the population, i.e. its average age. Unfavourable economic situation, linked to the transition from the state to a market economy, respectively the privatization of state enterprises, after the fall of communism, had a significant influence on the unfavourable demographic situation.

The data for Serbia were obtained from the Statistical Office, for Russia from the State Committee of the Russian Federation on Statistics, and for other European countries from the following sites: www.ined.fr, http://data.worldbank.org, 
http://epp.eurostat.ec.europa.eu, http://knoema.com/atlas. The aim of this paper is to point out the differences of demographic trends in former communist countries Serbia and Russia compared with other European countries with different political systems, in 2011. The demographic trends in other former communist countries (all former Yugoslav and Soviet republics) were similar. The fall of communism has affected all spheres of life of the inhabitants of the former communist states, but without doubt that influence, even after two decades, is reflected in the shaping of contemporary demographic trends.

The total fertility rate in only three European countries has a value that is higher than $2.1 \%$, that is, the expanded reproduction of the population is provided only in Turkey, Ireland and Iceland, while the lowest value of $1.21 \%$ was recorded in Hungary. The same complicated situation we can see in Russia, where this rate is $1.5 \%$. Natural population growth is negative in 16 European countries. Life expectancy has increased in all countries, with significant difference between Western and Eastern Europe. The increasing share of population older than 65 years is present in most countries of Europe. The fertility of the youngest fertile contingent of 15 to 19 years has declined due to change in the age birth model and increase in the average age of women at first birth. Infant mortality rates also decline in most countries, thanks to the improvement and advancement of health protection.

While on the one hand, in most countries, an increase is recorded in life expectancy and the share of the elderly, on the other hand, the decrease is recorded in total fertility rates, the decline in natural population growth and fertility of female adolescents and infant mortality rates. These processes have influenced the change in the demographic image of Europe, with significant differences at the country level, according to the economic, ecological, cultural, religious and other influences.

Demographic trends in Serbia, as one of the former Yugoslav republics, do not lag behind Europe. Serbia has recently recorded a constant population decline, and comparing the data from the 2011 census with previous census in 2002, a town of 311139 inhabitants disappeared. The total fertility rate is 1.41 , which is insufficient for the expanded reproduction of the population. With the reduction in fertility, an increase in the share of the population older than 65 years is recorded, as well as an increase in life expectancy. In this sense, there is a change in the balance of the old and the number of the active population and the increasing burden on the social fund. The fertility rate of adolescent girls in Serbia has a downward trend, as well as the infant mortality rates.

The modern situation in Russia, as one of the former Soviet republics, is connected with two main current trends: stable increase of the level of birth rate and migration of foreign population. The number of resident population of the Russian Federation in 2014 was about 143.7 million people, from which more than $70 \%$ live in cities and about $30 \%$ in villages. The growth of the Russian population has been observed since 2009 and it developed both at the expense of significantly decreased natural losses, and as a result of the increased migratory flow. 


\section{Demographic indicators}

\subsection{Total fertility rates}

Determination of the total fertility rate (TFR) is of great importance not only for determining the direction of motion of demographic trends, but it has application in the practical sense, that is, in determining the measures of population policy of a certain area or country. The total fertility rate as an indicator shows the potential of change in specific population in terms of a decrease or increase of the population, as well as the tendency of change in the average age of the population.

According to data for 2011 for Europe, the total fertility rates ranged from 1.2 in Hungary to 2.1 in Turkey, Ireland and Iceland. In almost all European countries TFR is below the level necessary for population replacement (2.1), except in the three mentioned states, while nine countries have TFR below 1.5, i.e. the value that McDonald called "low fertility trap" (Kupiszewski et al. 2010). "In most European countries the total fertility rate values dropped below the level needed for the reconstruction of the 70s and 80s of the 20th century" (Sobotka 2004).

The region of Northern and Western Europe is singled out as area with higher rates of fertility, where rates are higher than 1.8, while most of the countries of Central and Eastern Europe are characterized by values ranging from 1.2 to 1.5, except in Lithuania where the value is 1.8. Southern Europe is also characterized by lower total fertility rates (1.4 in Italy, 1.4 in Greece).

Many authors agree that the increasing unemployment of women has been the main cause of the fertility fall (Adsera 2005, Sobotka et al. 2011, Andersen and Ozcan 2012). In addition, there are numerous theories on fertility, such as the theory of the impact of socio-economic factors according to which a child is an

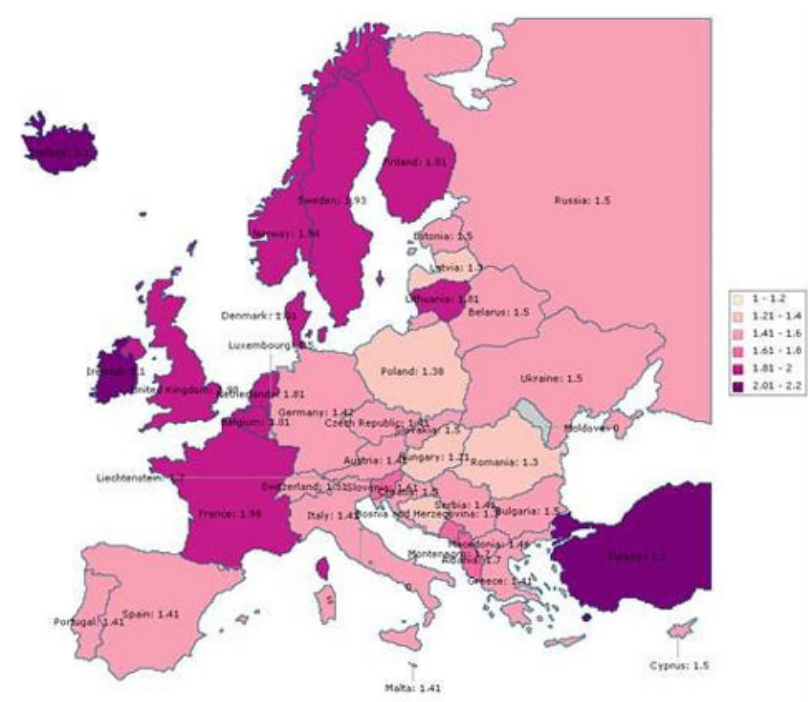

Figure 1. Total fertility rate according to 2011 data (Source: Made by the authors of the paper, 2015). 
expense (food, clothing, education, etc.), while to others the main factors of reducing the total fertility rate are the following: economic growth and increase of income, the decay rate of marriages and an increase in the share of cohabitation and the like. Reducing the total fertility rate carries with it a series of consequences, such as population ageing and a reduction in the workforce, because of the numerically smaller influx of population in the working contingent.

The total fertility rate in Serbia in 2011 was 1.4 live birth children per woman, which is insufficient for the expanded reproduction of the population. The publication "The Municipalities of the Republic of Serbia, the Main Demographic, Economic and Social Indicators Relevant to Population Policy", by Mirjana Rašević and Goran Penev, gives the average values of the total fertility rate data at the municipal level, for three-year periods 1990-1992, 2001-2003 and 20062008. In the first three years TFRs have recorded a continuous decline and on the level of the republic were: 1.72 in the first period, 1.58 in the second and 1.40 in the third. Observed by districts, in the first three years the City of Belgrade had the lowest TFR value of 1.54, the Pčinj District had the highest one of 2.55 , in the second, the Pirot District had the lowest value of 1.35, the Pčinj District also had the highest one of 2:33 and in the third period the Zapadnobacki District had the lowest value of 1.24 and the Raška District had the highest value of 1.89. At the same time, in the last period 2006-2008, the fertility rate was not recorded in any district, necessary to ensure replacement (Rašević, Penev 2009).

In neighbouring countries, the total fertility rates are also low - 1.3 in Bosnia, 1.41 in Macedonia, 1.5 in Croatia, etc. The war in Bosnia and Herzegovina, low socio-economic situation, massive migrations of young people have caused the low total fertility rate. The result is the depopulation with great demographic, economic and social consequences.

Russia in 2011 was on the verge of "low fertility trap" with a total fertility rate of 1.5. Measures to increase the birth rate were adopted in 1980, but the effect lasted only seven years, after which it decreased. Then the fertility rate was 1.9 children per woman, which was not enough for simple reproduction. New measures to improve population policy were adopted in 2007 . The total fertility rate increased from 1.3 (2006) to 1.57 (2010) (Frejka and Zakharov 2012). The number of born children per 1000 people of population increase in Russia every year from $9.8 \%$ in 2000 till $14.5 \%$ in 2013 . So a slight increase in the total fertility rate is positive, but still not enough for such a big territory of the country and in the coming years it will be seen whether the new measures have achieved the goal.

\subsection{Birth rates}

The population growth is a demographic indicator of the increase, that is, a decrease of population in a certain area, depending on whether the specified value is positive or negative. The population growth values are influenced by not only the number of births and deaths, but also by a number of specific factors that affect the natural movement of the population. Thus, the increased number of marriages or divorces affects indirectly the increased or decreased number of births. Also, 
throughout history, the emergence of certain diseases resulted in higher mortality, while finding cures and improving health care resulted in the decrease. The population growth as a result of these two components has varied over time in accordance with their changes.

The values of the population growth rates ranged from $-5.67 \%$ in Ukraine to $11 \%$ in Turkey. Negative population growth values were recorded in 15 countries, indicating an insufficient number of births. All the countries of Eastern Europe have a negative sign of the population growth values, the countries of northern and western Europe have positive population growth values, while the countries of central and southern Europe in terms of population growth values represent a mosaic, a combination of positive and negative values.

Turkey, as a country with the highest population growth value is in confessional terms a homogeneous country dominated by the Muslim population $(99.8 \%)$ with dominant views on pro-birth rate policy. Ukraine, as a former state of the Soviet Union, during its breakup experienced economic collapse, which among other things brought about the abolition of a number of incentives for raising children, which led to a decrease in fertility. With a mortality rate of $10.5 \%$, Ukraine ranks first in Europe. Per 100,000 people, there are more than 1,000 deaths from cardiovascular diseases (Marinković 2012). At the same time, the low birth rate of $-16.1 \%$ causes the lowest negative population growth in Europe. Population growth rate in Russia was negative (-3.58\%o) in 2011 as well as in the rest of Eastern Europe.

Data of the Statistical Office of the Republic of Serbia, based on the 2011 census, show that the population growth rate is positive in Serbia only in seven municipalities, Belgrade - Grocka, Novi Sad, Sjenica, Novi Pazar-town, Tutin, Bujanovac and Preševo, while Belgrade's municipality Zvezdara has zero natural growth. Moreover, in four municipalities, Novi Pazar-town, Tutin, Bujanovac and Preševo, the mortality rate is at the lowest level in the state. The result is the lowest average age of the population in these municipalities. A characteristic of these municipalities is that the population of Muslim denomination predominates. On the other side, the lowest birth rates are in Gadžin Han $(3.7 \%$ ), Rekovac (4\%o), Svrljig (4.1\%), and the highest mortality rates are in Crna Trava (35.7\%o), Babušnica (28.6\%o), Rekovac (26.8\%o), Svrljig (26.1\%o), etc. The listed municipalities are the most pronounced depopulating areas in Serbia. With the lack of natural regeneration of the population and expressed migration, the disappearing and extinction of many villages is going to happen in the not too distant future. That the situation in the country is alarming shows the fact that not a single child was born in 1.458 villages, while $82.5 \%$ of the villages had a negative population growth (RSO).

Russia, in comparison with other countries, has middle value of this rate $13.3 \%$. But it is also very different in different regions of the country. The highest birth rate is in the south of the country and the lowest one at the western regions. Also in Russia the ratio between man and woman at the birth is rather steady. In Russia on each 100 newborn girls there are registered 105-106 newborn boys. 


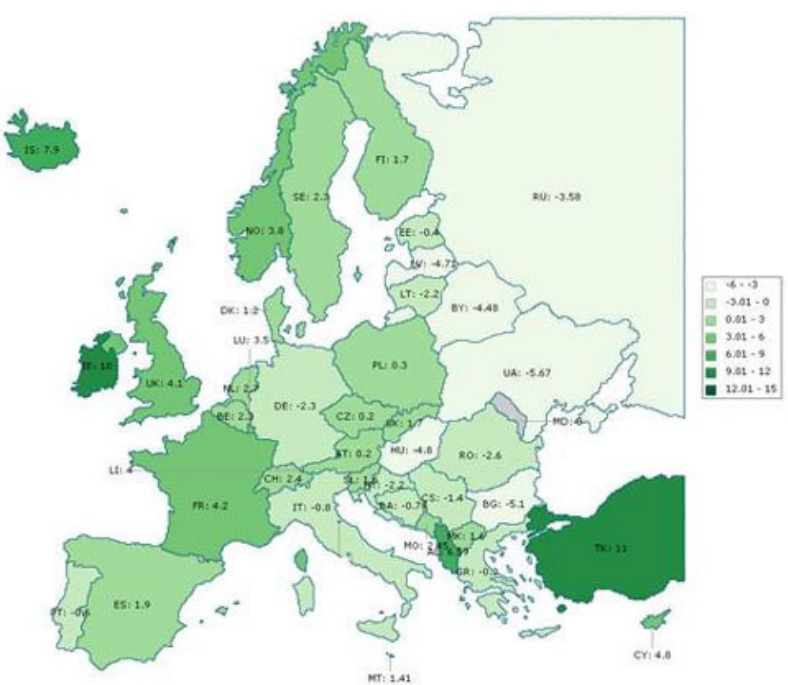

Figure 2. Rates of population growth per 1,000 people according to 2011 data (Source: Made by the authors of the paper, 2015).

\subsection{Life expectancy at birth day}

Life expectancy at birth day $\left(\mathrm{e}^{\mathrm{o}}\right)$ "represents the number of years a live-born child can expect to live, provided that the distribution of deaths by age does not change but is the same as the time when the tables are created. This ratio is independent of the age structure of the population and may serve as an indicator of socio-economic development of a country and the health status of the population. $\mathrm{E}^{\mathrm{o}}$ is a biometric function that is obtained from the mortality tables. Given that the life expectancy is a synthetic indicator of mortality and reflects the mortality at all ages of life, it is also used in comparative analyses of mortality" (Devedžić 2006).

On the map of Europe, shades of the same colour show the range of life expectancy in European countries, from the lowest value of 68.5 years, which is the life expectancy in Ukraine to 82.3 years in Switzerland. In this regard, lighter shades indicate lower values, while the darker shades refer to higher ones. The countries for which there are no data are represented in grey. Looking from west of Europe to east, darker shades are gradually replaced by lighter ones. Northern, north-western, western, south-western, southern and western part of central Europe are characterized by higher values of life expectancy that range from 79.5 years in Portugal to 82.3 years in Switzerland. Countries belonging to this block are characterized by a higher level of socio-economic development in relation to the countries in which the values of life expectancy are lower.

Besides having the lowest value of population growth, Ukraine has the lowest value of life expectancy at birth day of 68.5 , which is 13.8 years less than in Switzerland. Life expectancy in Serbia is 73.7 years -76.8 years for women, 71.6 years for men (Statistical Office). Observed since 1950, life expectancy in Serbia continued to grow. Thus in 1950, the life expectancy for women was 57.9, that is 54.4 for men. "The period of the $70 \mathrm{~s}$ was characterized by a slower rise of $\mathrm{e}^{\circ}$, 


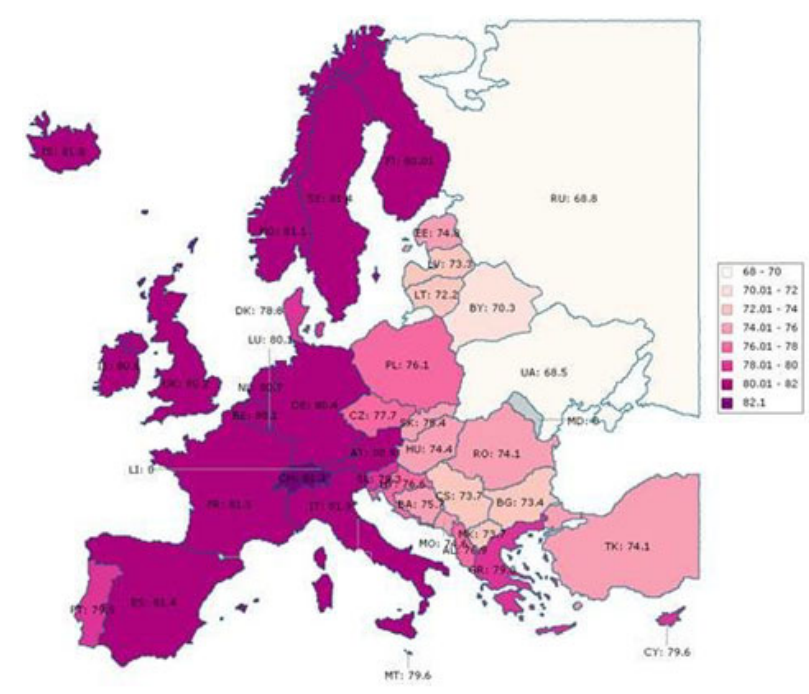

Figure 3. Life expectancy at birth day according to the 2011 census (Source: Made by the authors of the paper, 2015).

followed by a stagnation of this indicator during the 80 s. In the next decade, a decline in life expectancy followed, especially for men, because of the wars and the collapse of the socio-economic system. These negative trends reversed positive in the last decade" (Kupiszewski et al. 2012).

The continuous growth was influenced by two important factors: the improved living standards and improving health systems. "The initial reason for the extension of the average life expectancy is reduction of the mortality of infants, children and young population on the basis of which all countries have experienced a significant increase" (Devedžić 2006). The residents of Japan are the longest-lived, where the medium life expectancy for men is 79 years and for women even 86 years. Thus, the female Japanese have been on the top of the longest-lived in the world for 25 years in a row.

Life expectancy in Russia was 68.8 in 2011. The situation is much more favourable than 60 years ago, when in 1950, male life expectancy was 57 years, and women 71 years. According to data from 2011, the life expectancy for men is 64.3 and women 76.1 years. The listed causes of death in the last 20 years are heart diseases and external causes including accidents (70\% of total mortality), whereof even 3.2 million is on traffic accidents, murders, suicides and alcohol poisoning (Denisenko 2012). Life expectancy varies by regions, and in Moscow it coincides with a trend of Eastern Europe, while in the Republic of Tyva it is in line with the trend of underdeveloped African countries. The aim was to reach the life expectancy of 70 years by 2016, but that number has already been reached in 2011, so further plans are optimistic. 


\subsection{The share of population older than 65 years}

Demographic ageing is "a consequence of long-term decline in fertility rates and its keeping low, and then aided by significant prolongation of the average life expectancy, especially in developed countries where mortality is declining and in the older population, which accelerated the process of demographic aging from the top of the age pyramid" (Radivojević and Nikitović 2010).

The dominance of darker shades on the map shows that population ageing is a phenomenon that is observed in almost all European countries, regardless of their level of development. According to data from 2011, among European populations, Germany has the largest share of elderly over 65 years; even $20.7 \%$ of the population, i.e. more than $1 / 5$ of the population of Germany is over 65 years of age. On the demographic map of Europe, the following countries belong to a group of the oldest: Italy (20.3\%), Greece (19.3\%), Portugal (19.1\%), Sweden (18.5\%), etc. On the other hand, these countries have the smallest share of population over 65 years of age: Turkey (only 6.2\%), Albania (9\%), Ireland (11.5\%), Macedonia (11.7\%), etc. The ageing process is mostly recorded in low-fertility areas, in most European countries the population is ageing.

The reasons affecting the ageing population of Europe vary from country to country, but the consequences are almost the same in each of them. Low fertility rate and the extension of life expectancy are given as the main causes of ageing, while the consequences are an increasing share of the elderly in the total population and the irrational ratio of the old and the active population.

According to the share of the old, Serbia is classified in one of the oldest states not only in Europe, but also in the world. "More than 950,000 persons in central Serbia and about 300,000 persons in Vojvodina, that is, one sixth of both populations, are 65 years and over" (Rašević 2010). At the same time, the number is increasing from year to year, while the share of young is smaller, with a downward trend. According to 2011 data, $17 \%$ of Serbia's population is older than 65 years. Municipalities in Serbia with the highest average age are: Crna Trava, Gadžin Han and Svrljig, and municipalities with the lowest share of old age population are: Tutin, Novi Pazar and Sjenica (RSO). "The current age structure of the population of Serbia was formed under the direct influence of fertility, mortality and migrations, but also under the strong influence of inherited age composition, that is, under the influence of demographic inertia" (Stojilković 2011).

A similar scenario is expected in the future. "According to the latest revision of projections of the Republic Statistical Office of Serbia (RSOS 2011), the share of the older population in the overall share will increase in Serbia in all forms, from $16.9 \%$ in 2010 to over $20 \%$ in 2050" (Zdravković et al. 2012). The characteristics of the ageing population in Serbia are that this process takes place from the top of the age pyramid. The consequences are much greater numbers of old compared to young and active population, the burden of the social fund, an increasing number of old, poor people but also the problem of introducing the older population in society. 


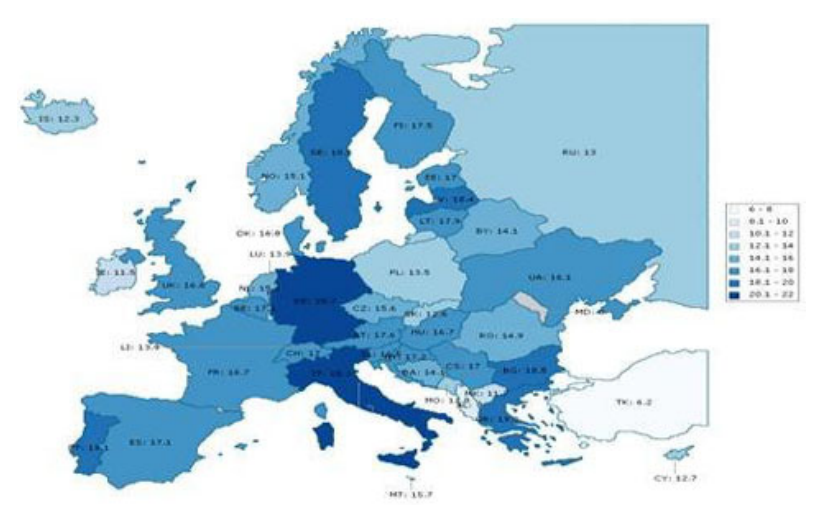

Figure 4. Proportion of the population aged 65 and over as a percentage, according to data from 2011 (Source: Made by the authors of the paper, 2015).

According to data from 2011, in Russia $13 \%$ of the population is older than 65 years. One of the causes of this situation is the low fertility rate and reducing mortality rate. Another group of factors included war and socio-economic shocks that befell Russia in the 20th century. It is believed that in 2025, each fourth resident will have more than 65 years. Unlike developed countries that will age from "above" because the life expectancy is elevated, in Russia this process will run from the "bottom" due to low birth rates.

\subsection{Fertility rates of fertile contingent aged 15-19}

"From a demographic standpoint, the group of adolescents aged 15 to 19 years is a significant group of the population and future demographic trends depend on their reproductive health and behaviour" (Stanković 2000). Pregnancy of adolescent girls, often unplanned, can cause a number of consequences on the mother and the child. Mothers are still insufficiently matured psychologically, developed physically, hurt socially and because of child care often forced to leave school and thus reduce the chance of later employment. As for the child, there is a danger of a temporary birth, low body weight, even subsequent risks of developing disorders. Therefore, it is necessary to implement a comprehensive policy that would lead to a reduction of these risks.

Data on the specific fertility rates of the youngest group of fertile contingent of 15 to 19 year olds for Europe show large differences in the lowest and highest values. Mapped values of adolescent fertility rates show a great homogeneity of the region of Europe. Most countries of the former Soviet Union are characterized by higher adolescent fertility rates, while on the other side, the countries of northern, central, southern and western Europe, except Great Britain (30\%,), have low adolescent fertility rate. The lowest adolescent fertility rates were recorded in the Netherlands and Switzerland and amounted to $4 \%$, while the highest value of $38 \%$ was recorded in Bulgaria, which is almost ten times higher compared to the lowest value. "Large differences in tradition, cultural values and moral standards, 


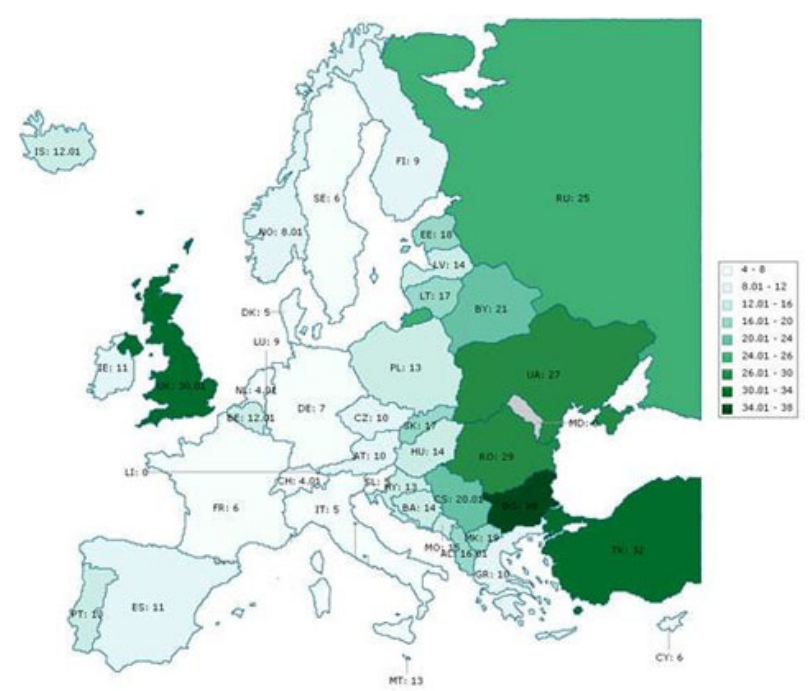

Figure 5. Fertility rates of the fertile contingent of 15-19 years, according to 2011 data. (Source: Made by the authors of the paper, 2015).

economic development, national structure, fiscal and social policies of the European countries are reflected in the fact that the value of the highest rate is generally ten times higher than the lowest" (Stanković and Penev 2012).

The Netherlands is the country with the lowest rate of abortions among adolescent girls. In addition, low fertility rates may be the consequence of the relatively free attitudes of the early entry into sexual relationships and educating teenagers on the application of contraceptives. According to van Loost who emphasizes the role of cultural and contextual factors, "the Netherlands compared to Great Britain is to a greater extent a traditional society with a developed family structure and family solidarity, greater involvement of parents in planning and defining the school curriculum, lower prevalence of single-parent families and less present culture of poverty" (Stankovic and Penev 2012).

On the other hand, Bulgaria is faced with the highest adolescent fertility rate. The reason is that the modern methods of contraception are relatively unknown to adolescents. Only a small number of the adolescents use some form of contraception in the form of contraceptives that are available in stores and pharmacies.

In the Republic of Serbia, according to the 2011 census, of 195026 women aged 15 to 19 years, 5.129 children were born, whereof 2.686 illegitimately and 2.226 legitimately (RSO 2011). The total figure is two times lower than the number of births in 1990, when 11.457 babies were born. Specific fertility rate is $20.02 \%$, which is significantly higher than the European average. The tendency to reduce the number of births is important primarily because of the preservation and improvement of the reproductive health of adolescent girls.

The fertility rate of adolescent girls in the Russian Federation was 25\% in 2011. This rate is among the highest in Europe, but the result is stagnation. 
Namely, in 1980 for adolescents aged $15-19$ years, fertility rate was even $43.8 \%$, it was $55 \%$ ten years after and since then has steadily decreased. In the period 1999-2008, this demographic indicator ranged 27.3 and $29.3 \%$. The number of children who were born in illegitimate unions decreases at mothers between 20 and 34 years of age, while the number remains the same or increases in other age groups. For the age group 15-19 years, the proportion of children born in illegitimate unions was 18.7\% 34 years ago, reached a peak in 2005 (48.4\%), and was 47.4\% in 2011 (Višnevskij 2013).

\subsection{Infant mortality rates}

One of the most important indicators of a society transition is a decline in infant mortality rates, and in post-communist countries Serbia and Russia these are lower than in communist era. Data from 2011 showed that the infant mortality has been a major problem in many countries, particularly the eastern European ones. Specific mortality rates are the highest in Albania (16\%), Turkey (13\%o), Romania (11\%), Bulgaria (11\%), Russia (9\%), etc. In Albania, which is at the bottom of the European scale, the infant mortality rates are particularly high in rural areas, which are caused by the lack of sufficient number of health care institutions, the use of traditional medicine and the domination of the population with low levels of education.

On the other hand, Iceland, Liechtenstein, Luxembourg and Sweden have the lowest infant mortality rates, only 2 per 1,000 births. In addition to Finland, according to data from 2011, which is one of six European countries with the lowest mortality rate of children aged up to one year, no maternal death was recorded in the same year (Statistics Finland 2011).

In comparison with the European average, the infant mortality rate is still relatively high in Serbia. According to the 2011 census, a total of 414 infants died in Serbia. Observing by districts, the highest value was recorded in the Rasinski District (the municipalities of Aleksandrovac, Brus, Varvarin, Krusevac-town, Trstenik and Ćicevać), 9.9\%o, and the lowest value was 2.9\%o in the Zapadnobacki District (the municipalities of Apatin, Kula, Odzaci and Sombor-town). The mortality rate at the republican level is $6.3 \%$. Compared to the developed countries of Europe it is a high value, which "points to the need for better preventive measures, especially in relation to infant mortality and other adverse pregnancy outcomes, as the key indicators of health and health care of mother and child" (Milanković 1998).

The infant mortality rate in 2011 in Russia was 7.3\%. In Europe, six countries are characterized by a higher rate than Russia and they are: Albania, Turkey, Bulgaria, Romania, Ukraine and Macedonia. Latvia and Slovakia have approximately the same mortality rate as Russia. The lowest infant mortality rate in Russia was recorded in 2011 in the North-Western Federal District (5.4\%o), and the highest one in the North-Caucasian Federal District (12.9\%o). Observing by districts, the lowest rate is in Tambovskaja area (4.1\%), which belongs to the 
Central Federal District, and the highest rate is characterized by Chechen Republic $(17.5 \%)$ in the North-Caucasian Federal District.

Table 1. Demographic indicators based on data from 2011

\begin{tabular}{|c|c|c|c|c|c|c|}
\hline 2011 & TFR & $\begin{array}{l}\text { Population } \\
\text { growth rate }\end{array}$ & $\begin{array}{c}\mathrm{e}^{\mathrm{o}} \text { at live- } \\
\text { birth }\end{array}$ & $\begin{array}{c}\text { Fertility rates } \\
\text { of adolescent } \\
\text { girls }\end{array}$ & $\begin{array}{l}\text { Infant } \\
\text { mortality } \\
\text { rates }\end{array}$ & $\begin{array}{c}\text { Share of elderly } \\
65+(\text { in } \%)\end{array}$ \\
\hline Serbia & 1.57 & -1.4 & 72 & 20 & 6 & 17 \\
\hline Andorra & / & / & / & / & 3 & / \\
\hline Albania & 1.7 & 6.59 & 76.9 & 16 & 16 & 9 \\
\hline Austria & 1.4 & 0.2 & 78.3 & 10 & 3 & 17.6 \\
\hline Belarus & 1.5 & -4.48 & 70.3 & 21 & 4 & 14 \\
\hline Belgium & 1.81 & 2.3 & 77.8 & 12 & 3 & 17.1 \\
\hline $\mathrm{B}$ and $\mathrm{H}$ & 1.3 & -0.78 & 75.7 & 14 & 6 & 14 \\
\hline Bulgaria & 1.52 & -5.1 & 70.7 & 38 & 11 & 18.5 \\
\hline Croatia & 1.5 & -2.2 & 73.9 & 13 & 4 & 17.2 \\
\hline Cyprus & 1.5 & 4.8 & 79.3 & 6 & 3 & 12.7 \\
\hline The Czech Republic & 1.4 & 0.2 & 74.8 & 10 & 3 & 15.6 \\
\hline Denmark & 1.8 & 1.2 & 77.8 & 5 & 3 & 16.8 \\
\hline Estonia & 1.5 & -0.4 & 71.2 & 18 & 3 & 17 \\
\hline Finland & 1.8 & 1.7 & 77.3 & 9 & 2 & 17.5 \\
\hline France & 1.98 & 4.2 & 78.7 & 6 & 3 & 16.7 \\
\hline Germany & 1.42 & -2.3 & 78.4 & 7 & 3 & 20.7 \\
\hline Greece & 1.41 & -0.3 & 78.5 & 10 & 4 & 19.3 \\
\hline Hungary & 1.21 & -4.8 & 71.2 & 14 & 6 & 16.7 \\
\hline Macedonia & 1.46 & 1.6 & 73.1 & 19 & 8 & 11.7 \\
\hline Iceland & 2.1 & 7.9 & 80.7 & 12 & 2 & 12.3 \\
\hline Ireland & 2.1 & 10 & 78.3 & 11 & 3 & 11.5 \\
\hline Italy & 1.41 & -0.8 & 80.1 & 5 & 3 & 20.3 \\
\hline Latvia & 1.3 & -4.7 & 68.6 & 14 & 7 & 18.4 \\
\hline Liechtenstein & 1.7 & 4 & 79.5 & / & 2 & 13.9 \\
\hline Lithuania & 1.8 & -2.2 & 68.1 & 17 & 5 & 17.9 \\
\hline Luxembourg & 1.5 & 3.5 & 78.5 & 9 & 2 & 13.9 \\
\hline Malta & 1.41 & 2.4 & 78.6 & 13 & 5 & 15.7 \\
\hline Montenegro & 1.7 & 2.45 & 73.4 & 15 & 6 & 12.8 \\
\hline The Netherlands & 1.81 & 2.7 & 79.4 & 4 & 3 & 15.6 \\
\hline Norway & 1.94 & 3.8 & 79.1 & 8 & 2 & 15.1 \\
\hline Poland & 1.38 & 0.3 & 72.6 & 13 & 5 & 13.5 \\
\hline Portugal & 1.41 & -0.6 & 79.5 & 13 & 3 & 19.1 \\
\hline Romania & 1.3 & -2.6 & 71.0 & 29 & 11 & 14.9 \\
\hline Russia & 1.5 & -3.58 & 68.8 & 25 & 7 & 13 \\
\hline Slovakia & 1.5 & 1.7 & 75.4 & 17 & 7 & 12.6 \\
\hline Slovenia & 1.6 & 1.6 & 76.8 & 5 & 3 & 16.5 \\
\hline Spain & 1.41 & 1.9 & 79.4 & 11 & 4 & 17.1 \\
\hline Sweden & 1.93 & 2.3 & 79.9 & 6 & 2 & 18.5 \\
\hline Switzerland & 1.51 & 2.4 & 80.5 & 4 & 4 & 17 \\
\hline Turkey & 2.1 & 11.0 & 74.4 & 32 & 13 & 6.2 \\
\hline Ukraine & 1.5 & -5.67 & 68.5 & 27 & 10 & 16 \\
\hline Great Britain & 1.98 & 4.1 & 79.1 & 30 & 4 & 16.6 \\
\hline
\end{tabular}




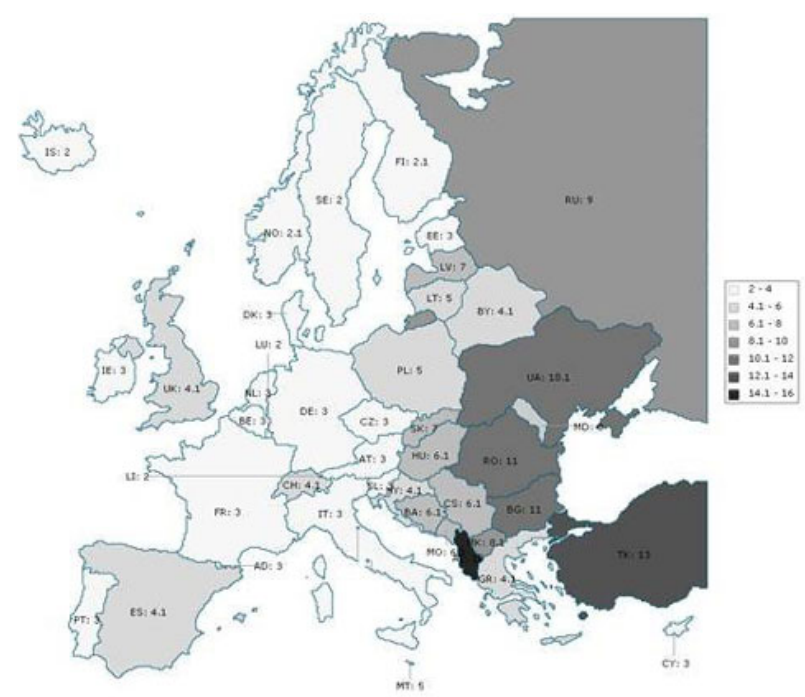

Figure 6. Rates of infant mortality according to 2011 data (Source: Made by the authors of the paper, 2015).

\section{Conclusion}

Most European countries in 2011 shared a similar fate in terms of demographic processes. The dominant processes in the developed countries of Northern, Western and Southern Europe are reducing fertility rates, increasing life expectancy and as a result of these two processes, an increasing share of the population older than 65 years. On the other hand, in underdeveloped countries (Albania) and countries with majority Muslim populations (Turkey), an increase in population is recorded, despite high rates of infant mortality. The difference between these two groups of countries is also reflected in the age pattern of fertility; in developed countries the average age of mothers at birth is significantly higher than in the less developed countries, so that the fertility rates of women of the youngest fertile contingent are ten times less than in the other group of countries.

The demographic picture of Serbia is characterized by depopulation processes due to the reduced fertility rates, increasing life expectancy, as well as the share of population older than 65 years. The fertility rate of the youngest fertile contingent is higher than the European average, as well as the rate of infant mortality, but significantly lower in relation to the values from previous years.

The Russian demographic situation is characterized by depopulation processes like in Serbia. It is due to the economic process which started in transition economics in 1995. But the reduced fertility rate is compensated by the migration of population from CIS countries by economic reasons. Also till now the share of elderly 65+ (in \%) in Russia is not so big as in EU countries and together with improvements in medicine services it has a positive influence on the prospects of population growth. On the other hand, the adolescent fertility rate in Russia is one 
of the highest in Europe and can be compared with Great Britain, which also argues for improvement of the demographic situation in Russia in the future.

The different demographic patterns in former communist and other European countries show the significant role of political factors in shaping of demographic pictures of one country. In case of Serbia and Russia, that impact was negative, and the final result of that influence is depopulation.

\title{
Acknowledgements
}

This paper is a part of the project 47007 III, grant of Ministry of Education, Science and Technological Development of the Republic of Serbia.

\author{
Addresses: \\ Suzana Lović Obradović \\ Geographical Institute "Jovan Cvijić" \\ Serbian Academy of Sciences and Arts \\ Đure Jakšića 9 \\ 11000 Belgrade, Serbia \\ E-mail: s.lovic@gi.sanu.ac.rs \\ Stefana Babović \\ Geographical Institute "Jovan Cvijić" \\ Serbian Academy of Sciences and Arts \\ Đure Jakšića 9 \\ 11000 Belgrade, Serbia \\ Natalia Shpak \\ Ural Federal University \\ Ul. Mira, 19 \\ 620002 Yekaterinburg \\ Sverdlovsk Oblast, Russia
}

\section{References}

Adsera, A. (2004) "Vanishing children: from high unemployment to low fertility in Developed countries". Education and Health of Women and Children 95, 2, 189-193.

Andersen, S. and B. Ozcan (2012) "The effects of unemployment on fertility". Available online at $<$ ec.europa.eu/social/BlobServlet?docId=4547\&langId=en>. Accessed on 10.07.2015.

Hoorens. S, J. Clift, L. Staetsky, B. Janta, S. Diepeveen, M.Morgan Jones, and J. Grant (2011) Low fertility in Europe: is there still reason to worry? Santa Monica, CA: RAND Corporation. Available online at <http://www.rand.org/pubs/monographs/MG1080>. Accessed on 09.07.2015.

Kupiszewski, M., D. Kupisyewska, and V. Nikitović (2012) The impact of demographic and migration flows in Serbia. [In Serbian.] International Organization for Migration, CBMM Project.

Marinković, I. (2010) "Classifying countries according to leading causes of death in the world at the beginning of the 21st century". [In Serbian.] Stanovništvo 1, 75-101.

Milanković, J. (1998) "Infant mortality according to causes of death" [In Serbian.] Stanovništvo 36, $1-2,105-124$. 
Murray, D. (2012) Germany's aging population, society, culture \& politics program. Available online at $<$ http://www.aicgs.org/2012/11/germanys-aging-population/>. Accsessed on 9.7.2015.

Radivojević, B. and V. Nikitović (2010) "Sustainability of the workforce in terms of intense demographic aging". [In Serbian.] Zbornik Matice srpske za društvene nauke 131, 455-464.

Rašević, M. and Penev, G. (2009) Municipalities of the Republic of Serbia, the main demographic, economic and social indicators relevant to population policy. [In Serbian.] Beograd: Društvo demografa Srbije.

Rašević, M. (2010) “About aging and age in Serbia". [In Serbian.] Zbornik Matice srpske za društvene nauke 131, 199-209.

Stanković, B. (2000) "Tendencies of adolescent fertility in low fertility population areas of Serbia" [In Serbian.] Zbornik Matice srpske za društvene nauke 109, 195-204.

Stanković, B. and G. Penev (2012) "Birth in adolescence". [In Serbian.] Socijalna misao, 19 3, 149 161.

Sobotka, T. (2004) "Is lowest-low fertility in Europe explained by the postponement of childbearing?". Population and development review 30, 2, 195-220.

Sobotka, T., V. Skirbekk, and D. Philipv (2011) "Economic recession and fertility in the developed world". Population and Development Review 37, 267-306.

Stojilković, J. (2011) "Growing number of pensioners and population ageing in Serbia". Journal of the Geographical Institute "Jovan Cvijic" SASA 61, 2, 69-84.

Zdravković, A., Domazet, I. and Nikitović, V. (2012) "The impact of demographic aging on the sustainability of public finances in Serbia”. [In Serbian.] Stanovništvo 50, 1, 19-44.

\section{Internet sources}

Eurostat. Available online at $<$ http://epp.eurostat.ec.europa.eu/portal/page/portal/eurostat/home $>$. Accessed on 26.2.2015.

Federal'naja služba gosudarstvennyj statistiki. Available online at $<\mathrm{http}: / / w w w . g k s . r u />$. Accessed on 26.2.2015.

Hodgson, An (2012) Ukraine's population in rapid decline. Available online at $<$ http:// blog.euromonitor.com/2012/05/ukraines-population-in-rapid-decline.html>. Accessed on 26.2.2015.

Knoema. World data atlas: world and regional statistics, national data, maps, rankings. Available online at $<$ http://knoema.com/atlas $>$. Accessed on 26.2.2015.

L'Institut national d'études démographiques (INED). Available online at $<$ www.ined.fr $>$. Accessed on 26.2.2015.

Statistics Finland. Causes of death, 2011. Available online at $<$ http://www.stat.fi/til/ksyyt/2011/ ksyyt_2011_2012-12-21_kat_007_en.html >. Accessed on 10.7.2015.

Statistics Finland. Population. Available online at $<\mathrm{https} / / /$ www.stat.fi $/$ til $/$ vrm_en.html $>$. Accessed on 26.2.2015.

The World Bank. Mortality rate, infant (per 1,000 live births). Available online at $<$ http:// data.worldbank.org/indicator/SP.DYN.IMRT.IN?display=default>. Accessed on 26.2.2015.

Vital events in the Republic of Serbia in 2011. Available online at $<$ http://webrzs.stat.gov.rs/ WebSite/repository/documents/00/00/72/39/SN40_srb_2011+bkorekt.pdf $\geq$. Accessed on 10.07.2015. 

